\title{
Asymptomatic Thoracic Kidney
}

\author{
FERNANDO J. DE CASTRO, M.D., HERMANN SCHUMACHER, M.D.
}

SOLATED asymptomatic intrathoracic kidney is a rare congenital anomaly. Approximately 30 cases have been reported, ${ }^{1-17}$ only four of them in children. $3,8,10,15$ We describe here a fifth child with asymptomatic thoracic kidney, stressing the importance of intravenous pyelography with any patient who has an asymptomatic radiopaque lower thoracic mass.

\section{Case History}

A ten-monthold white girl was referred to the University of Michigan Medical Center because of an asymptomatic lower thoracic radiopaque mass found on chest $\mathrm{x}$-ray during an upper respiratory infection.

Physical examination on admission revealed normal rital signs and no phssical abnomalities. Lab. oratory studies included: white blood cell count of 9,600 with a normal differential, hemoglobin, 7.7 Gm. 100 ml.; normal urinalysis, reticulocyte count, $0.8 \%$; negative stool guatac, BUN, $15 \mathrm{mg} / 100 \mathrm{ml}$; and normal electrolytes.

Chest $x$-ray showed a radiopaque mass in the right lower thorax (Fig. 1a, b). An upper gastrointestinal series was normal, but an intravenous pyelogram showed the thoracic mass to be an ectopic right kidney (Fig, 10 ).

\section{Discussion}

Asymptomatic intrathoracic kidney is associated anatomically with either a diaphrag. matic eventration or a perforation, $1-17 \mathrm{Embry}$. ologically, as the early kidneys migrate cephalad from the pelvic portion of the coelom to their adull position th the abcominal open ing of the muscular part of the diaphragm closes off by proliferation of tisste above the kidneys, the pressure from below by the large suprarenal glands possibly contributing to the closure. ${ }^{3 x}$

From the Department of Pediatrics, University of Michigan, Ann Arbor, Mich, 48104.
Thus, there are two hypotheses for the development of intrathoracic kidney: (1) the ascending kidney and the suprarenal gland proceed too far cephalad and closure of the diaphragm occurs below them; or (2) there is defective development of the diaphragm at the particular site where the kidneys and suprarenal glands are rising. ${ }^{3}$

All thoracic kidneys reported before 1938 were found at autopsy. ${ }^{20,25}$. That year, Wolfromm ${ }^{17}$ reported the first asymptomatic thoracic kidney in a living 43 -yearold woman. Thirty cases have since been reported, most asymptomatic $^{2-17}$ and four with minimal symptoms of intermittent chest pain or hemoptysis. The four living children with isoIated intrathoracic kidney were asympto. matic. ${ }^{3,8,10,15}$

Most of the reported cases have been uncovered in routine chest $x$-rays. Conclusive diagnosis usually has been made by thoracotomy,

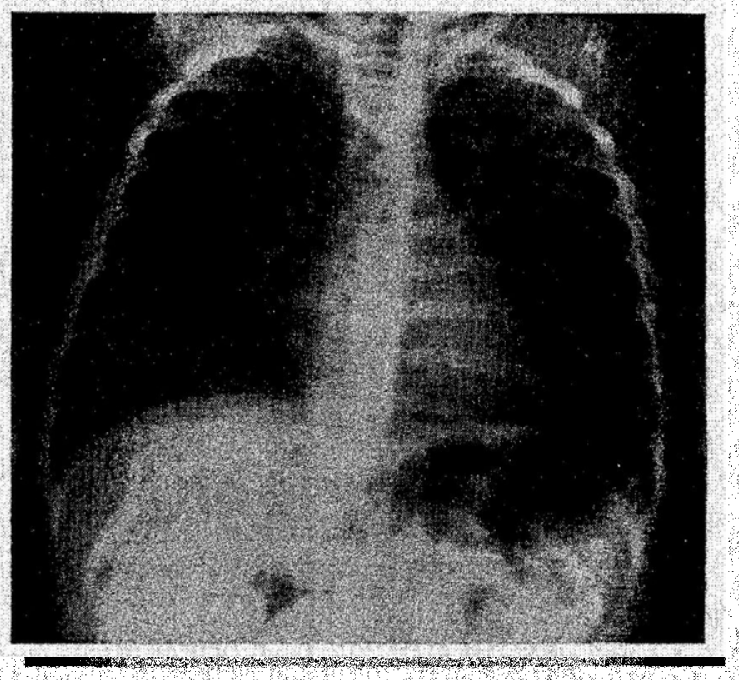

Frc, la Chest $\mathrm{x}$-ray (anteroposterior view) of ten. month old girl showing radiopaque nuss in tight lower thoma. 


\section{DE CASTRO AND SCHUMACHER}

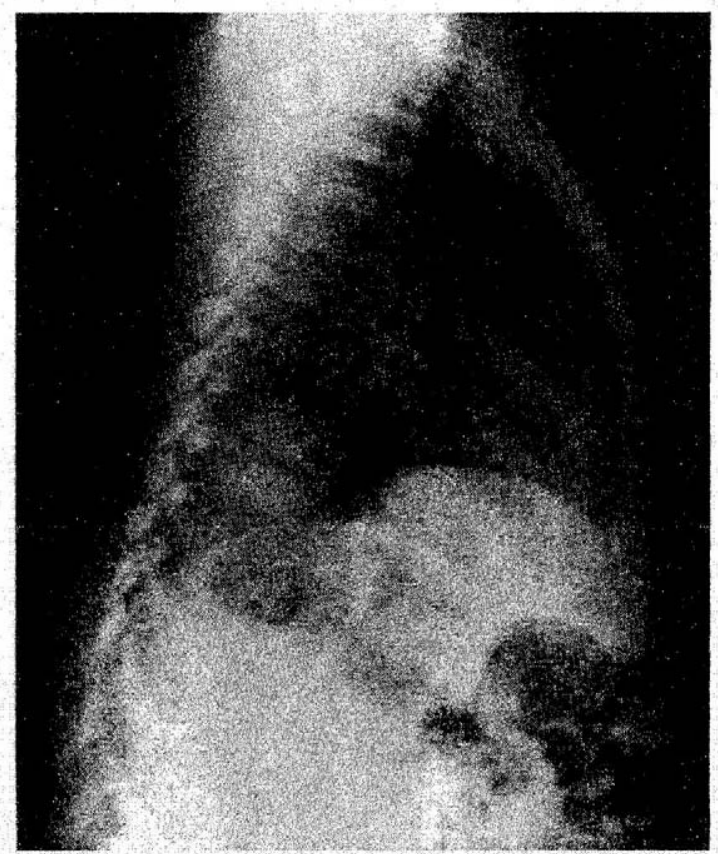

Fro. 1b, Chest $x$-ray (heral new) of same child showing mass in posterior lower right thorax which on intravenous pyelograply (Hig. 10 ) proved to be an ectopie right bidney.

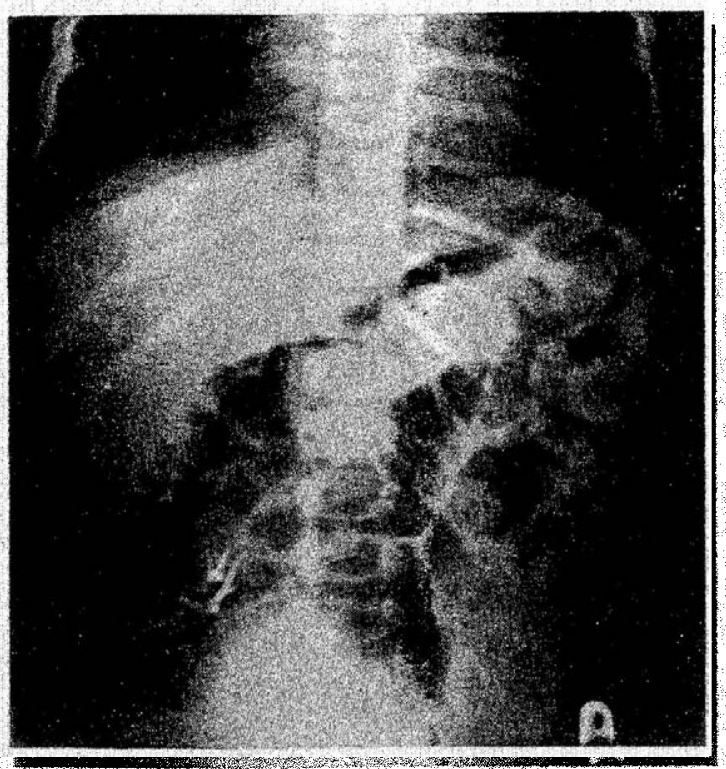

Ninc,

retrograde pyelography or meumoperito nem Fue cases $, 3,1,1,13$ were diagnosed by intravenous pyelography. Among the pedi. atric cases, two were diagnosed by thora- cotomy, ${ }^{80}$ one by pneumoperitoneum ${ }^{15}$ and one by intravenous pyelography. ${ }^{3}$

\section{Acknowledgment}

The authors thank Dr. William J. Oliver for his constructive criticism.

\section{References}

1. Barlow, J. W, Goodwin, W. E. and Vermooten, V.: Thoracic kidnev; case report. J. Utol. 78: 356 , $195 \pi$.

2. Baurys, W. and Servoss, S.: Eventration of the diaphragm: report of a case involving the kidney. Urol. Cutan. Rev. 53: 535, 1949.

3. Burke, E. C., Hent, U. E. and Utz, D. C.: The intrathoracic kidney; report of a case. Amer. J. Dis. Child. 113: $487,1967$.

4. Barret, N. R.: Right retroperitoneal diaphragmatic hernia. Brit. J. Surg. 32: 421, 1945.

5. Daroczi, Y.: Vierendystrophie in die Brusthöhle. Z. trol 49: 664. 1956.

6. Fleischner, P. G., Robbins, S. A. and Abrams, M.: High renal ectopia and congenital diaparag matic hernia. Radiology $55,24,1950$.

7. Franciskovic, $\checkmark$ and Martincic, N.: Intrathomcic kidney. Brit. J. Crol, 31, 156, 1959.

8. Hertag, $P$, Ectopic thoracique du rein droit. Le Poumon 6:501, 1950 .

9. Hill, J. E and Bunas, R. C. Thoracic kidney; case report. J. Urol 84: $160,1960$.

10. Laumonier, V., Freour, $\mathrm{N}$, and Delormos, M: Ec topic thoracique du rein droth Pommon Cocur 13: 119,195

11. Maggi, A. C. L, Mercroff, M. and Segel, J. E Erentration ditphagnatica congenita distrofra cecal superior y ectopia renal alta. Rey. Brasil. Gastroent. 6: 570, 1954

12. Pavi, A. T. S, and Urogada, I. G. Thoracic kid. ney, report of a case. Brit. I. Surg $47.395,1960$.

18. Robbins, J, J and Lich, R, Jt. Thoracic kidney. J Urol $72,153,1954$

14. Spillane, R, J, and Prather, G, C, High renal ectopy a case report. J. Urol 62. 441, 1949.

15. Spillane, R, J and Prather, G. C. Right diaphisagnatic eventration with renal displace, case report lbid. 68:804.

16. Willans, R, $\mathrm{C}$ and Tillinghart, A. I. Diaph herniation of the kidney; case neport. Radiology 53 . 366,1949

7. Wolfromo, G. Sitution dit rein days 1eventration diaphragmatic droit Men. Acad, Chir, (Pais) 36: 44,1940 .

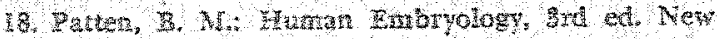

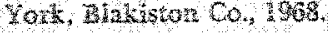

19. Davis, I, Human Development Anatomy. New York, Ronald Peess Co, 1969.

20. Campbell, If. Fenal ectopy, f. Urol 24 . 187, 1930.

21. Chambrelant, J, and Princetean, W. R. J. Ned. Borden $97,99,1897$ 